
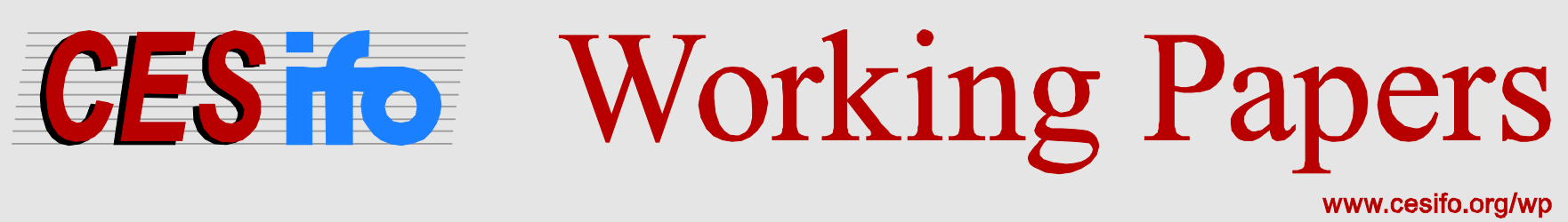

\title{
Neo-Protectionism and the European Lobbies
}

\author{
Marianna Belloc
}

CESIFO WORKING PAPER NO. 4832

CATEgory 8: TRAde Policy

JUNE 2014

An electronic version of the paper may be downloaded

- from the SSRN website:

- from the RePEc website:

- from the CESifo website:

www.SSRN.com

Www.RePEc.org

www.CESifo-group.org/wp

\section{CESifo}




\title{
Neo-Protectionism and the European Lobbies
}

\begin{abstract}
This paper empirically explores the connection between two recent phenomena in the European scenario: the dramatic upsurge of non-tariff trade measures and the remarkable rise in the role of European business lobbies. While these two facts have been widely recognized by the international trade and the political economy literature, empirical investigation into the connection between the two has so far been impeded by the lack of data. To identify European special interest groups and their influence on policy decisions, we construct an original dataset by collecting information on the participation of national and international organizations in the European Commission consultations on trade issues and by merging it with newly released information on non-tariff measures aggregated at the tariff-line level. Drawing upon the panel structure of the dataset, we find that European lobbies exert an important influence on the policy-makers, even after controlling for product fixed effects and a number of product and industrial variables. Between two possible interpretations of this finding, either that participation in meetings captures political pressure (possibly including the supply of biased information) on policy-decisions or that it involves, rather, transmission of true information, our empirical results tend to favor the former. Nonetheless, we are inclined to rule out the possibility that registration in consultations is in itself just signaling for active involvement in lobbying action, since we find evidence that actual meeting attendance has a larger impact on policy decision than registration only.
\end{abstract}

JEL-Code: F140, F150, D720.

Keywords: trade policy, neo-protectionism, European Union, lobbying, political economy.

Marianna Belloc

Department of Economics and Law

Sapienza - University of Rome / Italy

marianna.belloc@uniroma1.it

May 23, 2014

I wish to thank Pol Antràs, John C. Beghin, Giancarlo Gandolfo, Giovanni Maggi, Alessandro Nicita, and Ben Shephard for comments and useful discussion, Emanuele Mazzini for valuable research assistance, and Didier Bloch for generous help with the data. Any remaining error remains my own. Finally, I wish to thank the Department of Economics at MIT for generous hospitality over the period that saw this paper drafted. 


\section{Introduction}

World trade is on a much smaller scale than predicted by theoretical models although there is little disagreement, among international economists, about the welfare benefits of free trade. This is still true in the twenty-first century, although multilateral trade negotiations have appreciably brought down tariff barriers in the past thirty years, especially among the developed countries. While tariff measures have seen considerable reduction, however, neo-protectionist and regulatory trade instruments have proliferated (Beghin, 2006; Orden et al., 2012; WTO, 2012). According to a copious literature (surveyed by Gawande and Krishna, 2003), one reason is that powerful business groups steer trade policy in their favor and seize welfare benefits at the cost of the consumers. Measuring the pressure exerted by lobbies and the effects of their actions on trade policy is empirically challenging. With the one exception of the United States, where campaign contributions from special interest groups are legal and hence registered, lobbying is in fact an underground activity, and thus difficult to monitor and quantify, which is why most of the literature on lobbies and trade policy has focused on the United States. In this paper, the focus is on the European Union.

The European Union offers an especially interesting and challenging environment to study. Generally speaking, the measures for lobbying action in the European Union are similar to those adopted in a nation state: economic contributions, information provision, political support, and so on. However, the policy environment that characterizes the European Union is much more complex than a national system, as it relies on a very open and decentralized decision-making process. This provides the business groups with additional and often alternative avenues to exert pressure on policy-makers. Identifying this activity is challenging because, as in many other countries, the European political institutions do not officially allow exchanges of campaign contributions for policy favors, with the consequence that political support and consultations between business groups and politicians cannot be tracked. But there is another possibility that can be explored, and which we describe below.

Policy proposals are drafted by the European Commission, which has the power of initiative in trade and regulatory matters. The Commission's role is that of a supranational body; it is essentially a technical bureaucracy that resorts to a large extent to private actors to gather information needed to draft legislation. Thus, lobbies represent an important 
source of grass-roots information and play a very active role during the legislative process: they bring issues to the policy makers' attention, provide information, and often take part in the committees (Directorates-General) that assist the Commission in preparing proposals (Broscheid and Cohen, 2003).

In this paper we measure the participation of lobbies in forming trade policy using the participation of business groups in the regular meetings on external trade matters organized by the European Union Directorate-General for Trade ${ }^{1}$ (the Trade Civil Society Dialogue) and involving the European Commissioner for trade, the senior Commission officials and the trade negotiators (European Commission, 2012). While consultations between the European Commission and civil society started in 1998, regular meetings have only been held since 2001. Registration is compulsory for attendance, the registration tool procedure for organizations having been established in 2002. Registration and attendance are cost-free and travel expenses can be refunded by the Commission for organizations that are not resident in Brussels. On this evidence we can rule out the possibility that the richest lobbies self-select into the Dialogue. We collected information on the number of organizations registered in each meeting that took place between 2002 and 2006 and on whether or not they in fact attended the respective meetings. After classifying this information in industrial manufacturing categories, we matched it with data on non-tariff measures $^{2}$ aggregated at the tariff-line level (8-digit of the Harmonized System ${ }^{3}$ ) in 1999 and 2007, and with data on other industrial and trade variables at the sector and product level for the same time span. Having the possibility to observe non-tariff measures before and after the official meetings were launched, we are able to disentangle the effects of the consultations on European policy decisions.

Figure $1 \mathrm{~A}$ depicts the change in the average number of imported product categories subject to NTMs as a percentage of the total number of imported product categories (average frequency ratio) before and after 2001 for four countries, India, Japan, Mexico, and the European Union. ${ }^{4}$ As one can notice, NTMs protection has dramatically increased

\footnotetext{
$1 \quad$ DG-Trade hereafter.

2 NTMs hereafter.

3 HS hereafter.

4 Unfortunately, data on NTMs are scanty and very few countries allow us such a comparison. TRAINS-
} 
in such period, but more remarkably in the European Union, where it rose from 0.15 to $0.73 .^{5}$

\section{FIGURE 1A ABOUT HERE}

Figure 1B shows the correlation between the cumulative number of the European Union Trade Civic Society Dialogue meetings attended by at least one organization between 2002 and 2006 and the European Union average frequency ratio in 2007 computed for each industrial category (4-digit of the International Standard Industrial Classification ${ }^{6}$ ). As will be seen, there is a positive and statistically highly significant correlation between the two. This association is suggestive, but could, of course, be merely the spurious outcome of many omitted and confounding factors: they will duly be taken into account through our estimation strategy.

\section{FIGURE 1B ABOUT HERE}

By exploiting the panel structure of the dataset, we find that the industrial categories that registered and participated in the meetings more often than others tend to be associated with larger levels of NTM protection in the period considered, even after controlling for a number of time variant industrial and product characteristics and the fixed effects at the product level. In addition, we are able to distinguish across different non-tariff measures, and in particular core measures and non-core measures (as described in subsection 3.1), and investigate the differential effects of lobbying on each of them. We find that our results are driven by non-core measures, the increase in which over the period considered turns out to be largely determined by European lobbying activity. This finding is consistent with the idea, well documented in the literature (e.g. Coate and Morris, 1995; Ponzetto,

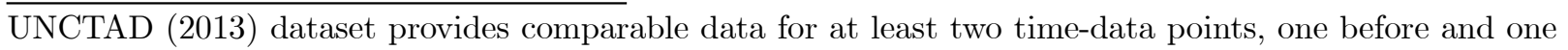
after 2000, for India (1997 and 2005), Japan (1996 and 2004), Mexico (1999 and 2006), and the European Union (1999 and 2007). Available classification is consistent across years (more recent data are available, but the coding system of trade control measures changed in 2009 and the data would be poorly comparable with previous versions).

5 Notice that our data are roughly comparable with figures offered by Nicita and Gourdon (2013), which refer to 2012 for Mexico (0.54), 2009 for Japan (0.40), and 2010 for the European Union (0.9). Data reported by Nicita and Gourdon are not available for India.

6 ISIC hereafter. 
2011), that "sneaky" and opaque policy measures are the preferred policy instruments to favor pressure groups.

It would be interesting to discriminate between two possibilities. One possibility is that the European associations use the Civil Society Dialogue meetings for true information transmission, in which case the sectors regulated with stricter non-tariff measures tend to be those that have real justification for such regulations. The second possibility is that the organizations that register and participate most in the meetings are those that aim to exert their influence through channels other than mere consultation (including biased information provision), in which case participation in meetings would capture lobbying political pressure. In the former case lobbying activity would be helpful to officials and Commissioners needing to learn the characteristics of the products and of the industries that should be considered to define regulatory instruments; in the latter the meetings would be an occasion for lobbies to steer policy decisions in their favor. We tend to prefer the second interpretation for two reasons. First, in our analysis we can control for several industrial and product characteristics and for product level fixed effects that are likely to capture technical features that would justify regulation. Second, when we include among the controls additional variables capturing the incidence of NTM protection in three important trading partners of the European Union (Japan, India, and Mexico), we find that the effect of participation in meetings is not significantly altered. Hence, if anything drives industrial groups to participate in public consultations, it does not seem to be worldwide objective characteristics of products.

One may then be tempted to conclude that just registration in the Dialogue signals lobbying activity. Fortunately, we are able to distinguish between organizations that only register in the meeting and then fail to show up, and organizations that actually attend the meeting. We find that simple registration has a positive and statistically significant effect on the strictness of NTMs, but this effect is considerably more limited than that of actual attendance. Of course we cannot rule out the possibility that, besides participation in meetings, other forms of pressure are exploited by the European lobbies to influence the policy-makers. However, we deem it plausible that traditional lobbying (mostly pressure on national politicians) has remained more or less constant over the sample period (see also Karakaovali and Limão, 2008) and is, as a consequence, washed out by the fixed effects. 
This paper is structured as follows. In the next section we briefly review the related literature, while in section 3 we introduce the institutional and policy-making environment of the European Union. In section 4 we describe the data and the empirical strategy. Section 5 discusses the results. Finally, section 5 sets out our concluding remarks.

\section{Related literature}

This paper contributes to the empirical literature on the political economy determinants of trade policy. Starting from the influential study by Baldwin (1985), a large number of contributions have provided empirical assessments of the validity of political economy theories of protection, mainly focusing on the United States' economy (see, for instance, Trefler, 1993, and, for a comparison among different approaches, Gawande, 1998). Reviews of this literature are provided by Rodrik (1995) and Gawande and Krishna (2003).

In the past twenty years, most of the effort in this literature has been devoted to test the predictions of Grossman and Helpman ${ }^{7}$ (1994)'s protection for sale model, according to which the level of protection in a given industry and in a given country is the level that maximizes a combination of the general welfare and the contributions of the special interest groups. Limitations in the empirical tests of the GH model have been emphasized by recent works (Imai et al., 2009a, 2009b), but over and above these problems, the GH approach would not apply to the object of our interest. The protection for sale framework is in fact particularly suitable for electoral systems where the mobilization of potential voters and the provision of campaign finances can be used to exert pressure on decision-makers, but not very well equipped for the European environment where policy initiatives are taken by technicians that do not compete for re-election. While this paper does not adopt the GH framework for the reasons just explained, in subsection 5.3 we verify that our results are robust to the inclusion of the variable used by the literature to capture the GH effect in the presence of organized lobby groups.

We depart from the literature in the strategy used for the identification of industries that are politically organized to sheer trade policy. As regards the United States, for

\footnotetext{
7 GH hereafter.
} 
instance, Gawande and Bandyopadhyay (2000) and Goldberg and Maggi (1999) resort to corporate political action committees (PACs) campaign contributions and define as organized industries that allocate resources to political contributions over a certain cutoff level. This choice presents a major problem: it does not allow to distinguish the amount of money that lobbies address to sway trade policy's decisions from those that are directed to other goals (for instance domestic support not related to trade). Unlike the above studies, Kee et al. (2007) include PACs contributions in the estimated regressions, rather than using them to classify industries.

In our case, however, contributions data do not exist, as they are prohibited in European countries. To overcome this problem Karacaovali and Limão (2008) assume that all the European industries are organized, whereas Belloc and Guerrieri (2007) adopt proxy variables that, while useful to distinguish between national and European groups, do not allow to single out pressure groups with specific regard to trade policy. McCalman (2000)'s strategy is based on information by Australian trade policy institutions. Exploiting the Australian practice of reviewing any operation of trade policy by an independent advisory body (the "Tariff Board"), the author classifies an industry as organized if a Tariff Board report was prepared in the given period. However, this strategy remains specific to Australia. Our strategy is closer to Mitra et al. (2002) who map the membership to one of the most important Turkish industrialist organizations (the TUSIAD ${ }^{8}$ ). The main pitfall here is that identification cannot capture pure trade policy concerns being the TUSIAD a general (both domestic and international) interest business organization.

We deal with the aforementioned concerns by using participation in the DG-Trade Civil Society Dialogue meetings as we explain in subsection 4.2 in greater detail. Our strategy allows us to attain two goals. First, we tackle a specific feature of the European Union institutional arena, where lobbying is wielded mainly at the early stages of the policy formation process through information provision and negotiations with the European Commission. Second, we are able to focus on interest groups with pure trade policy concerns. To the best of our knowledge, the present work is the first attempt to provide direct measures of lobbying activity at the European level.

\footnotetext{
8 Turkish Industrialists and Businessman Association.
} 
Finally, the present paper relates to the recent contributions on the relevance of nontariff measures in world trade. As is largely documented by the literature, regulatory and other non-tariff instruments (that have been used in the last couple of centuries) started to proliferate in the '90s (Nicita and Gourdon, 2013; Basu et al., 2011). Although they are not necessarily protectionist, NTMs represent one of the most important sources of international trade costs (Anderson and Van Wincoop, 2004; Hoekman and Nicita, 2011). This is especially true for the developed countries, for which traditional protectionist measures have become increasingly difficult to use, given the WTO negotiations and multinational free trade agreements (Coughlin and Wood, 1989; WTO, 2012). More sophisticated, less evident, but sometimes equally discriminatory instruments have recently taken the place of tariffs and quotas. Empirical evidence in this field has so far been impeded due to serious data limitations. To the best of our knowledge, the present paper is the first to explore the determinants of non-tariff protection in the extra-union European trade.

\section{European institutional environment and non-tariff protection}

Before the adoption of the Single European Act (SEA) in 1987, European policy-making was mainly in the hands of the Council of Ministers and individual governments had the veto power. As a consequence, most of the lobbying activity was performed by national groups along political and administrative channels (Mazey and Richardson, 1993, 2001). Since adoption of the SEA this situation has changed remarkably. The Commission has been endowed with the power to initiate European Union policies and has become a crucial actor in the formulation of policy proposals. This entails a special need for coalition-building at the European level in the early stages of the lobbying process. The commissioners are (supposedly) independent of the national member states and have the status mainly of technicians. This has increased the role of business groups in assisting the Commission in drafting policy proposals and has stimulated more active debate among stakeholders. In particular, the Trade Civil Society Dialogue holds regular meetings on external trade matters between the European Commissioner for Trade, the senior Commission officials and the trade negotiators (European Commission, 2012). The main goal of these meetings is to foster confident working relationships between all stakeholders interested in trade policy 
issues and to gather the basic information the Commission needs to draft legislation.

In the period under investigation the European Union made extensive use of non-tariff measures for trade protection purposes. For instance, Hanson (2010) documents that between 2002 and 2006/2007 two of Europe's major trading partners and competitors, the United States and Japan, raised a remarkable number of issues (forty) against the European Union regarding import-related matters. A substantial portion of them concerned social protection, environmental initiatives and food protection. In a significant number of cases the WTO dispute resolution system ruled against the European Union, proving that the regulations were discriminatory and favoring European producers. In some other cases disputes were not settled, European regulations were not emended, and interpretations remain unclear. Examples of standards and technical requirements that provoked complaints are: the REACH (Registration, Evaluation, Authorization and Restriction of Chemical substances) concerning environmental policies (European Union, 2006), the WEED (Waste from Electrical and Electronic Equipment Directive) regarding recovery/recycling requirements (European Union, 2002b), the RoHS (Hazardous Substances in electrical and electronic equipment) relating to the use of hazardous materials (European Union, 2002a). Several other issues came in for considerable debate, including pharmaceutical and medical device regulation and sanitary and phytosanitary requirements (e.g. the Genetically Modified Organisms and the Wood Packaging Material Directives).

\section{Data description}

\subsection{Trade protection data: NTMs and tariffs}

The two most obvious trade protection measures are tariffs and NTMs, and the choice between the two is fraught with important implications (Gawande and Krishna, 2003). On the one hand, adopting an index of NTMs (discussed below) as a measure of trade protection is likely to exhibit large measurement errors that can lead to either over-estimating or under-estimating the extent of protection since NTMs are not necessarily protectionist (Nicita and Gourdon, 2013). On the other hand, adopting tariffs would most probably imply under-estimation of protection due to the extensive use of new trade measures made by most of the industrialized countries which has in recent times come to substitute the 
traditional policy instruments. What we would need are ad-valorem equivalents of trade protection that measure overall trade restrictiveness including both tariff and non-tariff measures. However, this index, constructed for single European countries, is available for a single time observation (Kee et al., 2009) and would not allow us to exploit any time variation. Hence, though acknowledging the above shortcomings of this choice, we use data on non-tariff measures (NTM) provided by the UNCTAD-TRAINS (2013). Data available are for 1999 and 2007 only $^{9}$ and are aggregated at the tariff line level, which is the level of aggregation at which trade policy is set.

There are two main approaches in identifying the incidence of NTMs. The first relies on the coverage ratio $\left(c_{i}\right)$, defined as the share of the value of imports in each product group covered by an NTM. In symbols $c_{i}=\left(\sum_{k=1}^{K} d_{k} v_{k} / \sum_{k=1}^{K} v_{k}\right)$, where $d_{k}$ is a dummy variable that equals 1 if one (or more) NTMs is (are) present for product $k$ (8-digit HS) within each product group $i$ (6-digit HS) and zero otherwise, whereas $v_{k}$ is the value of imports of product $k$. The second approach employs the frequency ratio $\left(f_{i}\right)$, defined as the number of imported product categories subject to NTMs as a fraction of the total number of imported product categories in each product group. In symbols $f_{i}=\left(\sum_{k=1}^{K} d_{k} m_{k} / \sum_{k=1}^{K} m_{k}\right)$, where $m_{k}$ is a dummy variable that equals 1 if product $k$ is imported and zero otherwise; while the other symbols are already known.

Both indexes have shortcomings. First, they provide no information about the economic (prices and volumes) effects of NTMs (Deardorff and Stern, 1998). Second, missing information cannot be clearly interpreted since it is not clear whether the lack of HS codes means that NTMs do not exist for those product categories or simply that the data are missing (Carrère and De Melo, 2011). In addition, the coverage ratio suffers from limitations due to the endogeneity of the value of imports: it may be that highly protected sectors turn out to have, as a consequence, low import flows; in the extreme case, if a product category is so protected that the value of imports is zero, the NTM on such a product is not counted in the coverage ratio. This problem does not affect the frequency ratio, which however is limited by the fact that it does not reflect the relative value of the imported product in the

\footnotetext{
$9 \quad$ Again, data are also available for 2010, but classified by a different coding system and therefore cannot be used for the present purposes.
} 
group (a product that is imported very little and one that is largely imported have identical weights within a given HS group, for instance). Despite these limitations, the coverage and frequency ratios are commonly used in the literature and are acceptable in our case as long as our main interest lies not in measuring the welfare/trade effects of NTMs but in the determinants of NTMs themselves. In this paper, we will in all cases report results for coverage ratios only since using frequency ratios would not change our conclusions in any significant way.

We are, of course, aware that NTMs are not necessarily trade barriers, and considering the two expressions as synonyms is a mistake. Nevertheless, the use of NTM to pursue protectionist goals is so widespread that they can, with an acceptable degree of approximation, be interpreted as a proxy for neo-protectionism with trade hindering effects. Take, for instance, electrical and electronic equipment, in the production of which the United States has a comparative advantage with respect to the European Union. For the production of electrical and electronic equipment there are objective reasons for regulation in connection with the use of hazardous substances, such as mercury, lead, hexavalent chromium (Electrical and Electronic Equipment Directive, European Union, 2002a), or the recovery/recycling of waste materials (Waste from Electrical and Electronic Equipment Directive, European Union, 2002b). Nonetheless, US producers complain about overuse of the regulatory instrument, which hides a protectionist purpose (Hanson, 2010; ECORYS, 2009). First, the technical requirements tend to be extremely demanding, possibly in excess of any technical justification, as in the case of the ban on nickel-cadmium batteries (European Union, 2006). Second, even when specific requirements are justified, lack of harmonization imposes extracosts on non-European exporters that alter the conditions of competition. In the United States there is no such thing as the European restrictions on the use of hazardous materials. It follows that American exporters incur, ceteris paribus, additional costs when the final market is the European Union. It goes without saying that similar complaints might be made, in turn, by European producers with respect to the regulations of their own trading partners, and so on.

The NTM coding system (UNCTAD, 2010) is consistent between 1999 and 2007 classifications. Following Basu et al. (2011) we distinguish between core and non-core measures as follows. Core measures include: 3 - price controls (e.g. anti-dumping measures); 4 (except 
417) - finance measures (e.g. advanced payment of customs duties); 6 (except 617, 627, 637 ) - quantity controls (e.g. seasonal quotas); 7 - monopolistic measures. Non-core measures include: 417 - refundable deposit for sensitive products; 617 - non-automatic license for sensitive products; 627 - quotas for sensitive products; 637 - import prohibition for sensitive products; 5 - automatic licensing measure (e.g. prior surveillance); 8 - technical measures (e.g. packaging requirement). The original sources for the European Union do not include categories 4 (finance measures) and 7 (monopolistic measures).

The differences across policy instruments implied by this classification are well known and awareness of the different justification and effects of each distinct measure, in general and in separate sectors in particular, is of course crucial to the present study. One consequence is that one might be tempted to take core and non-core measures as separate instruments for trade protection. While this exercise could be useful (and we will in fact bear in mind the importance of this distinction in commenting on our results), we must not, however, forget that the two forms of protection could be substitutes one for the other. Hence, for instance, a sector adopting hazardous materials is better suited for protection with technical requirements; quotas are more attractive in sectors where information costs are prohibitive and procedure transparency is hindered; industries involving livestock are clearly more easily protected by adopting sanitary and phytosanitary measures (e.g. WTO, 2012). This may be true even after taking due account of the real features of the product that need product-specific regulation and that offer well-founded technical justifications. It follows that overall protection, as resulting from core and non-core NTMs together, should be deemed the most appropriate quantification of non-tariff trade barriers, after controlling for time-fixed product characteristics.

In our empirical study, we also employ data on ad-valorem equivalents of MFN applied tariffs in the European Union (MFN 1999) drawn from UNCTAD-TRAINS (2013) and are aggregated at the 6-digit HS level. In addition, we construct measures on non-tariff protection incidence (overall, non-core and core protection) for Japan (NTM japan), Mexico (NTM mexico), and India (NTM india). Given that data on NTMs and imports for these countries are only available at the 6 -digit HS, we cannot obtain as fine measures of protection as for the European Union. Hence, we use a synthetic measure given by $f_{i}=d_{i} m_{i}$, where again $d_{i}$ is a dummy variable that equals 1 if one (or more) NTMs is (are) present 
for product $i$ (6-digit HS) and zero otherwise and $m_{i}$ is a dummy variable that equals 1 if product $i$ is imported and zero otherwise.

\section{FIGURE 2 ABOUT HERE}

Figure 2 shows the changes between 1999 and 2007 of the average overall, non-core and core coverage ratios as compared with the average MFN applied tariffs. As is evident, tariff protection decreased in the time span considered; by contrast, the NTMs increased dramatically, in general, and even more noticeably the non-core measures, whose coverage ratio jumped on average from 0.03 to 0.41 .

\subsection{Lobbying}

We use data from the Trade Civil Society Dialogue provided by the DG-Trade (European Commission, 2012). Since 2001 the Trade Civil Society Dialogue has been holding regular meetings on external trade matters between the European Commissioner for Trade, senior Commission officials and trade negotiators. The main goal of these meetings is to foster a confident working relationship among all stakeholders interested in trade policy issues and to gather the basic information that the Commission necessitates to draft legislation. The DG-Trade maintains a database of all the civil society organizations registered to take part in the meetings held each year. Registration is compulsory for attendance. In 2001 the European Commission launched a program to finance the participation of organizations in consultation meetings as long as they are not based in Brussels, the registration procedure being established in 2002. Meetings can be distinguished between those related to general trade issues (potentially of interest to any organization) and issues specific to the agricultural sector. In our analysis we consider only the former (hence excluding agricultural thematic meetings) since we focus on manufacturing sectors.

We collected information on which organizations registered for/attended each meeting between 2002 and 2006. Every sector is eligible to participate in the dialogue apart from the national European member states, which are not represented and often continue consultations at the national level. We confine our attention to business organizations in the manufacturing sector. Hence, we do not consider NGOs, think-tanks, workers' associations and so on because they cannot be linked to industrial sectors. We classify each organization 
according to the 4-digit ISIC system (Revision 3). Hence, we also know if a given organization represents more than one ISIC sector. For each organization we have also information about whether or not it in fact attended the meeting.

Since trade data (NTM indexes, trade, and import demand elasticities) are aggregated at the 6-digit HS, we matched industrial codes from 4-digit ISIC with codes from 6-digit HS. ${ }^{10}$ Here, the fact that the lobbying variable is at a higher level of aggregation than the trade variables should not create problems since producers, especially at the European level, have more advantage in organizing at the industry (rather than product) level to lobby for protection. This is confirmed by the fact that, in the European Union, there is more variation in protection across industries than within them (on this point see also Karacaovali and Limão, 2008).

Relying on these data, we construct the following variables: the fraction of meetings (over the total number of meetings held in the time span considered) attended by at least one organization in a specific industrial sector (meetings) between 2002 and 2006, the fraction of meetings (over the total number of meetings held in the time span considered) in which at least one organization in a given sector registered (regardless actual attendance) (registrations), the number of organizations in a given sector that attended at least one meeting in the time interval considered (organizations), the number of organizations in a given sector that registered with the Civil Society Dialog in the time interval considered (organizations reg), the number of multi-sector (i.e. more than one 4-digit ISIC category) organizations that attended at least one meeting (multi-sector), the number of single-sector (i.e. just one 4-digit ISIC category) organizations that attended at least one meeting (singlesector), and finally the fraction of meetings attended by respectively just one organization (just one) and more than one organization (more than one) in a given industrial category.

Table 1 sets out the descriptive statistics. The total number of meetings on trade matters held in this time span is 148 (36 in 2002, 30 in 2003, 26 in 2004, 30 in 2005, and 26 in 2006). Of course, more than one organization belonging to a given sector can participate in each meeting (so the number of presences per meeting can be greater than the number of meetings). Manufacture of Cocoa, Chocolate, and Sugar Confectionery (ISIC

\footnotetext{
10 Concordance tables are available at http://www.macalester.edu/research.
} 
1543) is the sector with the largest fraction of meetings in which at least one organization was present $(61 \%)$ or registered regardless of actual attendance (98\%), and the largest number of multi-sector organizations (7). Manufacture of Pharmaceuticals (ISIC 2423) is the sector for which the largest number (11) of organizations registered in the Civil Society Dialogue (regardless of their actual participation); of these, 7 attended at least one meeting. Manufacture of Dairy Products (ISIC 1520) is the sector with the largest fraction of meetings attended by more than one organization. Finally, the largest number of active (meaning attending at least one meeting) organizations (7) over the whole period is registered by all the three aforementioned sectors. The average annual fraction of attended meetings increased over time, rising from 0.06 in 2002 to 0.17 in 2006, attesting to the fact that industrial groups have increasingly recognized the importance of taking part in the public consultations.

\section{TABLE 1 ABOUT HERE}

\subsection{Trade data and import-demand elasticities}

We also need data on import and export values and import demand elasticities (elasticity). External European trade series, obtained from Eurostat (2012), consist in extra-EU trade statistics and cover the total trading of goods between any member state and a nonmember state. By goods we mean all movable properties. Data are at the 6-digit level of disaggregation according to the HS (import values are also downloaded at the 8-digit HS to compute coverage and frequency ratios within each 6-digit HS). To compute synthetic frequency ratios for Japan, Mexico, and India we also collect import data for these countries at the 6-digit HS which are available from UNCTAD-TRAINS (2013).

Import demand elasticities for the European Union are computed using data provided by Kee et al. (2004), which are suitable for our study for a number of reasons. First, they are disaggregated at the tariff line level, that is 6-digit HS (more than 4000 products in our case), so as to maintain consistency with the level of aggregation of the trade protection measure and trade data. This is important since we expect the import demand elasticities to be greater proportionally with the higher levels of disaggregation. As a consequence, using more aggregated data for import demand elasticities than for protection would lead to under-estimation of the welfare costs of protectionist trade policies. Second, they are 
obtained with a methodology that is consistent with trade theory and by employing the same data sources for each country and good considered. Finally, the estimates obtained present a good degree of accuracy. Considering the overall study by Kee et al. (2004), which includes 117 countries, $89 \%$ of the elasticities are statistically significant at the $1 \%$ level, $91 \%$ at the $5 \%$ and $93 \%$ at the $10 \%$ levels. Import demand elasticities are available from source for each European Union country member and were aggregated by weighted sum, the weights being the share of the individual country's imports over total imports. In the present paper we define import demand elasticities as always positive and trim data excluding observations respectively below and above the 1st and the 99th percentiles.

\subsection{Industry data}

Finally, we need data on industrial variables. These are provided by the OECD (2012) by country and detailed at the 4-digit ISIC level. Concordance with HS is achieved on the basis of the international systems concordance tables. The industrial variables used in estimation are: total number of employees (workers), industry scale (scale, obtained as the value added per firm), firm concentration ratio (concentration, proxied by the share of the total value of production by firms with 250 persons engaged or more), annual average earnings per employee (earnings), labor share (labor share, computed as the share of the value of production which goes to wages and salaries of all persons engaged, including social contribution, income taxes but not social security, pensions and other retirement contributions), number of unpaid persons employed (unpaid family workers and working proprietors) as a fraction of the total number of employees (unpaid), total number of R\&D personnel as a fraction of the total number of employees ( $r \mathscr{E} d$ personnel), investment in land as a ratio of value added (land), import penetration (imp penetration, computed as the ratio between imports and value added) and the ratio of export over value added (exp ratio). All the variables are ratios, while workers are measured in thousands of persons. Average annual earnings are in thousands of euro at 2005 prices.

Industrial variables are available from the source for each country member, so they need to be aggregated at the European Union level. The value added, the number of employees, the number of firms, the number of unpaid persons employed, the number of R\&D personnel and the investment in land are aggregated by simple sum; the labor share, the industry 
scale, the concentration measure and the import penetration ratio are computed for the European Union as a whole.

\section{$5 \quad$ Empirical strategy and main results}

We start by considering the following equation regression:

$$
N T M_{i t}=\lambda_{i}+\tau_{t}+\gamma \cdot x_{i t}+\delta \cdot z_{j t}+\varepsilon_{i t}
$$

where $t(=1999,2007)$ denotes time, $i$ and $j$ indicate respectively the product (6-digit HS) and the industry $j$ (4-digit ISIC). ${ }^{11} N T M_{i t}$ is an index of non-tariff measures for product $i$ and at time $t, x_{i t}$ and $z_{j t}$ are vectors of control variables respectively at the product $(i)$ or industry $(j)$ level at time $t . \lambda_{i}$ and $\tau_{t}$ are respectively product fixed effects at the product level and the time effect (since we only have two periods we include a dummy, time, that is equal to 1 if $t=2007$ and zero otherwise), and $\varepsilon_{i t}$ is the residual term.

Since we are interested in the effects of lobbying activity on NTM protection, in equation (2) we also include a proxy for lobbying influence (lobby):

$$
N T M_{i t}=\lambda_{i}+\tau_{t}+\beta \cdot \text { lobby }_{j t}+\gamma \cdot x_{i t}+\delta \cdot z_{j t}+\varepsilon_{i t}
$$

As already explained, consultations (in regular meetings) through the Civil Society Dialogue of the DG-trade started after 2001; hence in 1999 this form of lobbying activity was not present. We assume that the influence on the policy-makers by a given industrial sector $j$ in each year $t$ can be gauged by the participation in the Civil Society Dialogue on the part of organizations belonging to that industrial sector during the period spanning between the starting year of the regular meetings, $t_{0}$, and year $t$. Hence for each time $t>t_{0}$, we have:

$$
\text { lobby }_{j t}=\sum_{s=t_{0}}^{t} \text { participation }_{j s} .
$$

In our empirical analysis, we measure participation employing alternative variables such as the fraction of attended meetings, the fraction of registrations, the number of organizations attending, and others. Since in equation (2) we are controlling for product level

11 Of course industries are aggregations of products following the concordance tables. 
fixed effects as well as a number of time variant variables at the product and sector level, we should be able to isolate the role of lobbying influence produced through the regular meeting consultations (information transmission, negotiations, favor exchanges, possibly occurring in Brussels during the official meetings or related activities). Throughout the paper, we cluster standard errors at sector (4-digit ISIC) level.

\subsection{Estimation results: benchmark model}

First we are interested in finding out if the products that experienced a more dramatic increase in non-tariff protection are the same that used to be the most protected by tariffs at the beginning of the period considered. Hence, we estimate equation (1) without product fixed effects and including instead the level of ad-valorem equivalents of MFN applied tariffs in 1999 ( MFN 1999). The results are given in Table 2, columns (1), (2) and (3) respectively for overall, non-core and core measures. As will be seen, while the effects on core NTMs are close to zero, both economically and statistically, those on overall and non-core coverage ratios are positive and statistically significant, implying that between 1999 and 2007 these types of measures increased more sharply for products that were already characterized at the beginning of the period by a high level of tariffs.

\section{TABLE 2 ABOUT HERE}

Table 2, columns (4)-(5)-(6), also provides our estimation output for equation (1) including product level fixed effects. Let us start from the coverage ratio for overall non-tariff measures (column (4)). That protection increased on average (even after controlling for industry and product characteristics) between 1999 and 2007 is testified by the positive and statistically highly significant coefficient on the time dummy. As regards the other coefficients, we follow Baldwin (1985) and Gawande (1998) and distinguish between self-interested political component, altruistic political component, and comparative (dis)advantage component.

The first component is related with the idea that policy-makers, while setting trade policy, maximize their own interests, that is economic resources and votes in their favor (for a survey see, for instance, Gawande and Krishna, 2003). Even if, as we stressed in the introduction, European trade policy is to a large extent drafted by a technical bureaucracy, we cannot entirely rule out the possibility that traditional pressure mechanisms, possibly 
functioning at the national level, are also at work. In addition, policy-makers may be subject to pressure by lobby groups for exchanges of favors and such like. According to the "adding machine" model (Caves, 1976), the greater the voting strength of a sector, the more protection will be granted by the policy-makers interested in political support. Consistently, we find that the number of employees in a given sector (workers) increases the level of strictness of NTMs in that sector in a statistically significant way. Other variables can be interpreted as related with the strength of pressure groups such as the industry scale (scale) and the index of industry concentration (concentration). Collective action theories (Olson, 1965; Stigler, 1971; Brock and Magee, 1978; Findlay and Wellitz, 1982) suggest that industries differ in their ability to coordinate and get organized in lobbies due to free-riding problems. On the one hand, the bigger is the industry, the higher are the stakes involved in cooperation among producers in seeking protection. On the other hand, the bigger industries face more serious problems of collective action. Furthermore, lobbying activity is predicted to be positively correlated with industry concentration. We find that overall protection increases with decreasing industry scale and industry concentration, contradicting theoretical predictions. Yet, only the estimated coefficient associated with the first relation is statistically significant and it turns out to be consistent with the previous empirical evidence on NTMs offered by Gawande (1998). In addition, we also provide results for the effects of unpaid workers (unpaid workers). The estimated effect is negative and statistically significant. This result is not particularly surprising if we consider that family and self-employed workers may well be less effective in lobby organization efforts.

The second determinant of trade protection is associated with the presumption that altruistic government officials have a special regard for the lowest income groups (Ball, 1967; Constantopoulos, 1974). Accordingly, one would expect that sectors characterized by lower wages should obtain larger protection. We find that the estimated coefficient on annual average earnings (earnings) is negative, even if very small, and turns out to be statistically insignificant at any level of confidence. Similarly, one would expect that the higher the labor intensity, the higher should be the level of protection. This prediction is contradicted by our finding of a negative estimated coefficient on the labor share (labor share), in line with previous empirical evidence (see, again, Gawande, 1998). 
Finally, one would expect the products that the economy is more competitive at producing with respect to its major trading partners to be less in need of protection, and vice versa for less internationally competitive productions. Here, the share of research and development employees (rËd personnel) as well as the share of investment in land (land), which would capture respectively comparative advantage and disadvantage, have the expected signs but no statistically significant effects on protection.

The estimated coefficients on the import penetration ratio (import penetration) and on the ratio of export over value added (export/va ratio), consistently with predictions (Gawande, 1998), have respectively positive and negative signs and prove statistically significant at least at the $10 \%$ level. The trade price elasticity (elasticity) turns out to have no statistically significant impact on the dependent variable.

Considering our regression output when trade protection is proxied by alternatively non-core and core measures, shown respectively in columns (5) and (6) of Table 2, one can notice that results are in general consistent with those obtained for the overall protection index, with few exceptions that are never statistically significant.

\subsection{Estimation results: lobbying}

The goal of our subsequent analysis is to find out whether or not, even once time constant product features and time variant industrial and product characteristics are appropriately controlled for in the regression analysis, any role is left for European business groups in affecting policy decisions. Table 3 (respectively in columns (1), (2) and (3) for overall, noncore and core NTMs) shows our results when we estimate equation (2) and proxy lobbying activity by adopting the fraction of meetings attended by at least one organization in a certain industrial sector in the time span considered (meetings).

\section{TABLE 3 ABOUT HERE}

When we consider overall coverage ratios, the estimated coefficient on meeting participation is positive and highly significant from both the economic and the statistical viewpoints: sectors that participate more actively in the Civil Society trade meetings tend 
to obtain stricter non-tariff measures, even after controlling for product fixed effects ${ }^{12}$ and time varying industry and product level variables. Interesting findings are also obtained when we distinguish between core and non-core measures. Indeed, the lobbying effect is found statistically significant only when we consider the latter, whereas it is positive but not statistically significant when the former are used. The result that only non-core measures are significantly influenced by lobbying action is not surprising given our previous considerations and is open to two possible interpretations.

The first interpretation is that the level of protection granted through non-core measures reflects technical needs as regards, for instance, technical requirements for sanitary and safety standards, social protection, environmental initiatives, and so on. Accordingly, as already mentioned in the introduction and in section 2, the European Commissioners need information to define standards and requirements appropriately, and get real benefit from consultations. The fact that meeting participation and non-tariff trade barriers as resulting from non-core measures are positively correlated would then be the simple upshot of the fact that organizations from sectors that necessitate stricter technical measures tend to participate most in consultations to inform policy design. If this were indeed the case, Civil Society meetings would represent an arena to exchange useful information. With our data, we cannot entirely rule out this possibility. There are however two reasons why it does not seem particularly compelling. First, this interpretation requires two strong assumptions: one is that meeting participation always results in the supply of unbiased information; the other is that organizations self-select in consultations, or in other words that only organizations that have "true" information to convey actually participate in the meetings. These two assumptions are hard to defend in the real word. Second, for such an interpretation to hold, we should assume that the status of "sensitive" products (those products that require special treatment because their production is intensive in terms of hazardous materials, for instance, or more dangerous for the environment, the society, and so on) and the associated characteristics (level of risk of hazardous materials employed in production, to continue the example) are time variant so that their estimated impact on protection persists even after we control for fixed effects at the product (6-digit HS) level so

\footnotetext{
12 Employing industry, rather than product, fixed effects does not significantly affect the results.
} 
as to bias our coefficient of interest. Although we cannot completely rule out the possibility that some changes occurred in the production techniques or, perhaps, that awareness of the risks involved in certain production practices (in the example) increased over the time span considered, it is likely that most of those characteristics are washed out in estimation once the fixed effects are included.

Nevertheless, to investigate this possibility further we also include in our regression the incidence of NTMs protection by product category (6-digit HS) in Japan (NTM japan), Mexico (NTM mexico), and India (NTM india). The idea of this test is to consider the variation in regulatory measures that occurred in approximately the same time period under examination in non-European countries. Imagine that, during the time span considered, some important changes in the sector characteristics (including the level of hazardous material risk known by the policy-makers, in our example) occurred such as were able to influence the relative strictness of non-tariff measures, even after controlling for other industrial and product time-changing variables and the fixed effects (included in the regression). One might suspect these changes, if not appropriately accounted for, to be correlated with participation in the Civil Society Dialogue on the part of the industrial business groups, consequently misdirecting our interpretation. To take account of these considerations, we assume that if these changes occurred they should also be incorporated in policy decisions by other industrial countries that trade intensively with the European Union. The choice of the countries is dictated by data availability, pointing to Japan, Mexico, and India. ${ }^{13}$ The related output is shown in table 3, columns (4)-(5)-(6): as will be seen, previous results are substantially unchanged. The results (set out in columns (7)-(8)-(9) of table 3) are also substantially unaffected when we include as a regressor the average applied MFN in 1999 capturing the initial level of tariff protection (in this case product fixed effects are of course excluded).

The second possible interpretation of our results is that powerful business groups organized at the European level exploit Civil Society Dialogue meetings to exert pressure on

\footnotetext{
13 Unfortunately, NTM data for the US are available only for 1999, so that we would be unable to exploit time variation if we also considered this country. We choose all the countries for which two time observations, one before and one after 2001, were available.
} 
the policy-makers. Participation in meetings would in this case be a proxy for lobbying pressure: the more active groups at the European level also participate more intensively in the Civil Society Dialogue. Note that this interpretation does not necessarily imply that biased supply of information is the only (or the main) channel exploited by those groups to sway policy decisions in their favor. During meetings and consultations, lobbies may use biased information flows and/or other more traditional lobbying instruments, which may either complement or substitute one another. It is difficult to distinguish between these possibilities.

The latter interpretation is also consistent with the finding that non-core measures are affected by lobbying activity, while core measures are not. The reason is that the two policy interventions are subject to very different regulations within the WTO arena and tend to be set according to different negotiation regimes. Furthermore, they differ appreciably as regards transparency. On the assumption that citizens tend to be poorly informed on the effects of certain policy interventions, the political economy literature (see, for instance, Coate and Morris, 1995; with specific regard to the political economy of trade policy, see Ponzetto, 2011) suggests that politicians may prefer "sneaky" and opaque policy instruments to protect pressure groups. In this view, particularly convenient methods to favor special interests to the detriment of the general welfare are transfer mechanisms that may be justifiable on other grounds, such as environmental, safety, or health protection (Tullock, 1983). Core NTMs, such as price control, finance measures and quantity controls, tend to be more transparent and more easily detectable by the WTO than non-core NTMs, such as technical measures, refundable deposit or non-automatic license for sensitive products (WTO, 2012).

All the regressions above described also include the industry control variables commented in section 5.1. Estimated coefficients are not reported in table 3 for reasons of space, but coefficients that change sign (never statistically significant) are denoted in italics in table 2. As one will observe, conclusions are unaltered.

\subsection{Estimation results: additional findings}

As pointed out above, we cannot entirely rule out the possibility that meeting participation corresponds to true information transmission, although we deem it somewhat implausible. 
One extreme consequence of our interpretation might then be that it is not meeting attendance that matters, but simple registration in the Civil Society Dialogue. In this case, registration would signal active participation in lobbying action at the European level, even when the organizations do not in fact take part in consultations during the official meetings. Fortunately, our data allow us to distinguish between simple registration for meetings and actual attendance. Registration is free and compulsory to attend meetings, but once an organization has registered, it may or may not attend the meeting. As we have seen, travel expenses can be refunded by the European Commission, and so hardly constitute a likely reason for non-attendance after registration.

In figure 3 we show the correlation between the fraction of meetings in which at least one organization registered but no organization then actually attended the meeting and the fraction of meetings attended by at least one organization in each industrial category. The positive and statistically significant correlation illustrated in the picture suggests that the sectors that register for and attend consultation meetings more frequently than others are the same that, more frequently than others, register and are sometimes unable to attend (the estimated regression coefficient is 0.48 with a $t$-statistic equal to 16.50 ; the pair-wise correlation coefficient is equal to 0.92 statistically significant at any conventional level). In particular, there is no industrial group that registered in the Civil Society Dialogue and failed to attend so much as one single meeting.

\section{FIGURE 3 ABOUT HERE}

To evaluate the role of actual participation in meetings better, we investigate whether or not our results change when we substitute the meetings variable, which captures the fraction of meetings that at least one organization in a given industrial sector attended in the time span considered, for the registrations variable, which instead measures the fraction of meetings in which at least one organization in a given sector only registered. Note that registrations include registration with meeting attendance and registration with no meeting attendance, hence, by definition, the registrations variable is always equal to or larger than the meetings variable. Registrations, if anything, should capture signaling of organizations through the Civil Society Dialogue, whereas meetings should be able to identify effects of true lobbying activity. 


\section{TABLE 4 ABOUT HERE}

Columns (1)-(2)-(3) of table 4 show estimation results of equation (2) that are obtained by using registrations as a proxy for lobby. As compared with the regression output listed in columns (4)-(5)-(6) of the table 3 (in the most conservative scenario we consider regressions also including NTM japan, NTM mexico, and NTM india as controls), it will be seen that the effect of registration on the coverage ratio is much smaller than the effect of meeting attendance. In particular, the estimated coefficient is 0.2610 versus 0.4210 if overall NTM is considered (the two coefficients are statistically different at the $5 \%$ level with a chi-squared statistic equal to 8.82), 0.2296 versus 0.3730 if non-core measures are taken into account (the two coefficients are statistically different at least at the $10 \%$ level, the chi-squared statistic being equal to 3.53 ), and 0.0357 versus 0.1682 in the case of core-measures (statistical difference at $10 \%$ level, chi-squared statistic equal to 3.14 ). The above mentioned and the following regressions always include the industry controls and the non-tariff protection synthetic measures for Mexico, India, and Japan.

Similar conclusions are drawn when we estimate our equation substituting meetings with organizations, which is a variable measuring the number of organizations attending meetings in each industrial category, or organizations reg, which is a variable measuring the number of organizations registered in the Civic Society Dialogue (regardless actual participation in meetings). The results are set out respectively in columns (4)-(5)-(6) and (7)-(8)-(9) of table 4. As will be seen, a higher number of organizations in a given industrial sector is associated with greater overall and non-core protection, considering both registered only and attending organizations. Yet, again, the estimated coefficient on the number of organizations that actually participated in the meetings is much larger than that on the registered organizations, for both overall and non-core protection (the estimated coefficients are statistically different at any conventional level (chi-squared statistic equal to 5.50) in the first case and at the $15 \%$ level in the second case (chi-squared statistic equal to 2.19)).

\section{TABLE 5 ABOUT HERE}

Moreover, we are interested in identifying the more effective lobbies. The political economy literature (again Olson, 1965) suggests that coordination problems make lobbying by less dispersed groups more effective. Looking for evidence in favor of or against this predic- 
tion, we distinguish between the meetings attended by just one organization (just one) and the meetings attended by more than one organization (more than one). Results are given in columns (1)-(2)-(3) of table 5. Consistently with previous results, we find that the estimated coefficient on the latter variable is larger than that on the former variable. Moreover, as already explained in the data description, some organizations may represent more than one sector (meaning that their products belong to more than one 4-digit ISIC category). The question that arises is whether or not organizations speaking for multiple industrial sectors are more effective than single-sector organizations. In columns (4)-(5)-(6) of table 5 we consider as regressors the number of multi-sector (multi-sector) and single-sector (single-sector) organizations that attended at least one meeting. We find that, when we consider overall and non-core NTMs, the estimated coefficients associated with the former variable are always positive and statistically significant, whereas the parameters associated with the latter are never statistically significant (and even turn out to be negative, in some cases). These results testify that organizations representing more than one sector tend to be more effective in lobbying activity.

\section{TABLE 6 ABOUT HERE}

Finally, we deal with concerns related with our neglect of possible GH mechanisms of political economy influence on trade policy. In table 6 we deal with this issue. We include in our regression a political economy variable defined as $g h=($ elasticity/ipenet $) \times 100$. Under the assumption, already adopted by Karakaovali and Limão (2008) in their contribution, that all industries are organized in traditional lobbies (which, according to the prediction of the GH model, make pressure on policy-makers by offering monetary contributions or policy favors), the estimated coefficient on the $g h$ variable would represent the extra-weight attached to producers' surplus relative to social welfare in the European Union. Columns (1)-(2)-(3) of table 6 set out our regression output obtained including the gh but not the meetings variable (industry controls are always among the regressors). As one will notice the estimated coefficient on $g h$ is positive and statistically significant at the $10 \%$ level in the equation including overall protection as dependent variable (that is the variable used by the relevant literature) and at the $15 \%$ level when the dependent variable is non-core measures instead. This result is consistent with predictions of the GH model: the greater the import demand elasticity and the smaller the import penetration ratio the more the 
economy as a whole has to lose from protection and the less willing the government will be to grant favors to specific interest groups to the detriment of the general interest population. Our estimated coefficient, equal to 0.0014 , is in the range of coefficients found by the GH literature for the United States, going from 0.014 (Goldberg and Maggi, 1999) to 0.0003 (Gawande and Bandyopadhyay, 2000). Regarding the European Union, Karakaovali and Limão (2008) find a coefficient ranging from 0.003 to 0.004 for the period between the end of the '80s and the beginning of the '90s. Columns (4)-(5)-(6) of table 6 offer our results also including the meetings variable. They show that, while the coefficients of the $g h$ variable are now (still positive but) never statistically significant, the estimated coefficients on our preferred lobbying variable are comparable in size to coefficients given in columns (1)-(2)(3) of table 3, and statistically significant when the dependent variable is overall protection (5\% level) and non-core protection (10\%) level.

\section{Conclusions}

Industrial lobbies represent key actors in trade policy-making, as has been largely documented by the international trade and the political economy literature. Yet so far hardly any empirical evidence on lobbying activities in the European Union and their impact on trade policy outcomes has emerged due to lack of the relevant data. This is unfortunate since the European Union is one of the largest trade actors in the world. To the best of our knowledge, this paper is the first to empirically assess the role of lobby groups in the European environment and gauge their influence on trade policy decisions.

As regards trade policy analysis, the European Union represents a peculiar environment to study. On the one hand, unlike the United States, Europe holds monetary contributions by business groups to politicians to be illegal. As a consequence tracking any direct link between pressure groups and policy-makers is practically impossible. On the other hand, trade policy proposals are drafted by the European Commission, which is essentially a technical body. From this it follows that traditional forms of policy pressure, such as

electoral support, are (at least apparently) inhibited. Nonetheless, lobby groups have a strong influence, as evidenced by a copious literature. In particular, they represent an important source of basic information and play a very active role during the legislative 
process.

In this paper, we quantify the presence of lobby groups in the European policy arena and empirically assess their influence on trade policy formation drawing upon the evidence on the participation of business groups in the regular meetings on external trade matters organized by the Civil Society Dialogue among the European Commissioner for trade, senior Commission officials and trade negotiators. The compulsory registration procedure for organizations was established in 2002 and provided us with some useful evidence, including the number of organizations registered in each meeting, their names (from which we were able to identify the relevant sector), actual attendance in the meeting and other relevant information. These data, collected for the 2002-2006 period, were merged with other information on trade and industrial variables at the product and industry level between 1999 and 2007. By exploiting the panel structure of the dataset, we were able to isolate the role of lobby participation in consultations on NTM coverage ratios, which turns out important from both the economic and the statistical viewpoints, even after controlling for product fixed effects and a number of additional variables. We also unravel a number of further findings and, in particular, that attending the meeting is more important than just registering in the consultations, that sectors represented by a large number of organizations are more effective, and that sectors represented by multi-sector organizations are more protected than others.

While this paper makes positive steps in the direction of a better understanding of the European lobbies' activities and their role on trade policy-making, several important aspects remain unexplored. First, we disregard the presence of non-business groups (such as NGOs, think-tanks, workers associations, etc), being unable to associate them with any particular industrial sector. Second, we do not explicitly consider in our analysis the influence exerted by the member states that are not officially represented in the DGtrade regular meetings. Third, we are aware that public consultations are just the tip of the iceberg and a number of alternative avenues to exert policy pressure are open to both national and European lobbyists. These issues offer considerable potential for future research in this area. 


\section{References}

Anderson, J.E., van Wincoop, E., 2004. Trade Costs. Journal of Economic Literature $42(3), 691-751$

Baldwin, R.E., 1985. The Political Economy of U.S. Import Policy. MIT Press, Cambridge (MA)

Ball, D.S., 1967. United States Effective Tariffs and Labor's Share. Journal of Political Economy 75(2), 183-187

Basu, B., Kuwahara, A., Laird., S., 2011. Evolution of Non-Tariff Measures: Emerging Cases from Selected Developing Countries. Policy Issues in International Trade and Commodities. UNCTAD Study Series 52, 1-27

Beghin, J.C., 2006. Nontariff Barriers. Center for Agricultural and Rural Development, Iowa State University, 1-13

Belloc, M., Guerrieri, P., 2008. Special Interest Groups and Trade Policy in the EU. Open Economies Review 19(4), 457-478

Brock, W.P., Magee, S.P., 1978. The Economics of Special Interest Politics: The Case of Tariffs. American Economics Review 68, 246-250

Broscheid, A., Cohen, D., 2003. Insider and Outsider Lobbying of the European Commission An Informational Model of Forum Politics. European Union Politics 4, 1465-1165

Carrère, C., De Melo, J., 2011. Non-Tariff Measures: What Do We Know, What Should Be Done? Journal of Economic Integration 26(1), 169-196

Caves, R.E., 1976. Economic Models of Political Choice: Canada's Tariff Structure. Canadian Journal of Economics 9, 278-300

Coate, S., Morris, S., 1995. On the Form of Transfers to Special Interests. Journal of Political Economy 103(6), 1210-35

Constantopoulos, M., 1974., Labor Protection in Western Europe. European Economic Review 5, 313-318

Coughlin, C.C., Wood, G.E., 1989. An Introduction to Non-Tariff Barriers. Federal Reserve Bank of St. Louis 1, 32-46

Deardorff, A.V., Stern, R.M., 1998. Measurement of Nontariff Barriers. Studies in International Economics. University of Michigan Press, Ann Arbor

ECORYS, 2009. Non-Tariff Measures in EU-US Trade and Investment - An Economic 
Analysis. ECORYS, Nederland BV

European Commission, 2012. Civil Society Dialogue - Directorate-General Trade.

http://trade.ec.europa.eu/civilsoc/index.cfm

European Union, 2006. Directive 2006/66/EC of the European Parliament and of the Council of 6 September 2006 on Batteries and Accumulators and Waste Batteries and Accumulators and Repealing Directive 91/157/EEC

European Union, 2002a. Directive 2002/95/EEC on the Restriction of Use of Certain Hazardous Substances in Electrical and Electronic Equipment

European Union, 2002b. Directive 2002/96/EC of the European Parliament and of the Council of 27 January 2002 on Waste Electrical and Electronic Equipment (WEEE)

Findlay, R., Wellitz, S., 1982. Endogenous Tariffs and the Political Economy of Trade Restrictions and Welfare. In Jagdish N. Bhagwati (Ed.) Import Competition and Response. University of Chicago Press, Chicago, pp. 223-238

Gawande, K., 1998. Comparing Theories of Endogenous Protection: Bayesian Comparison of Tobit Models Using Gibbs Sampling Output. Review of Economics and Statistics 80, $128-140$

Gawande, K., Bandyopadhyay, U., 2000. Is Protection for Sale? Evidence on the GrossmanHelpman Theory of Endogenous Protection. Review of Economics and Statistics 82(1), 139-152

Gawande, K., Krishna, P., 2003. The Political Economy of Trade Policy: Empirical Approaches. In James Harrigan and E. Kwan Choi (Eds.) Handbook of International Trade. Basil Blackwell, pp. 213-250

Goldberg, P., Maggi, G., 1999. Protection for Sale: An Empirical Investigation. American Economic Review 89(5), 1135-1155.

Grossman, G.M., Helpman, E., 1994. Protection for Sale. American Economic Review 84, $833-50$

Hanson, D., 2010. Barriers to Free Trade: Non-Tariff Barriers in the European Union, Japan and United States. Edward Elgar, Cheltenham (UK)

Hoekman, B., Nicita, A., 2011. Trade Policy, Trade Costs, and Developing Country Trade. World Development 39(12), 2069-2079

Imai, S., Katayama, H., Krishna, K., 2009a. Protection for Sale or Surge Protection? 
European Economic Review 53(6), 675-688

Imai, S., Katayama, H., Krishna, K., 2009b. Is Protection Really for Sale? A Survey and Directions for Future Research. International Review of Economics 63 Finance 18(2), $181-191$

Karacaovali, B., Limão, N., 2008. The Clash of Liberalizations: Preferential vs. Multilateral Trade Liberalization in the European Union. Journal of International Economics $74(2), 299-327$

Kee, H.L., Nicita, A., Olarreaga, M., 2009. Estimating Trade Restrictiveness Indeces. Economic Journal 119(1), 172-199

Kee, H.L., Nicita, A., Olarreaga, M., 2004. Estimating Import Demand and Export Supply Elasticities. Econometric Society North American Summer Meeting 368: 1-23

Kee, H.L., M. Olarreaga, Silva, P., 2007. Market Access for Sale. Journal of Development Economics 82(1): 79-94

Mazey, S., Richardson, J.J., 2001. European Union: Power and Policy-Making. Routledge, London

Mazey, S., Richardson, J.J., 1993. Lobbying in the European Community. Oxford University Press, Oxford

Nicita, A, Gourdon, J., 2013. A Preliminary Analysis on Newly Collected Data on NonTariff Measures. Policy Issues in International Trade and Commodities. UNCTAD Study Series $53,1-32$

OECD, 2013. Structural and Demographic Business Statistics.

http://www.oecd-ilibrary.org/statistics

Olson, M., 1965. The Logic of Collective Action. Harvard University Press, Cambridge (MA)

Orden D., Beghin, J.C., Henry, G., 2012. Key Findings of the NTM-IMPACT Project. World Economy 35(8), 967-1088

Ponzetto, G., 2011. Heterogeneous Information and Trade Policy. Working Paper CREI, $1-69$

Rodrik, D., 1995. Political Economy of Trade Policy. In Gene M. Grossman and Kenneth Rogoff (Eds) Handbook of International Economics. Elsevier North-Holland, Netherland. Vol. 3, 1457-1494 
Stigler, G.J., 1971. The Theory of Economic Regulation. Bell Journal of Economics and Management Science 2(1), 3-21

Trefler, D., 1993. Trade Liberalization and the Theory of Endogenous Protection: An Econometric Analysis of U.S. Import Policy. Journal of Political Economy 101(1): 138160

Tullock, G., 1983. Economics of Income Redistribution. Studies in Public Choice. Springer: Boston

UNCTAD, 2010. Non-Tariff Measures: Evidence from Selected Developing Countries and Future Research Agenda. Trade Analysis Branch DITC - United Nations Conference on Trade and Development, Geneva

UNCTAD-TRAINS, 2013. Trade and Tariffs Raw Data. World Integrated Trade Solution (WITS). http://wits.worldbank.org/wits/

WTO. 2012. World Trade Report: Trade and Public Policies: A Closer Look at Non-Tariff Measures in the 21st Century. Research and Analysis - WTO, Geneva 


\section{Tables and figures}

Table 1 - Descriptive statistics: Civil Society Dialogue (2002-2006)

\begin{tabular}{lccccc}
\hline & Obs. & Mean & St.Dev. & Min & Max \\
\hline meetings & 117 & 0.16 & 0.20 & 0 & 0.61 \\
registrations & 117 & 0.25 & 0.29 & 0 & 0.98 \\
organizations & 117 & 1.82 & 1.99 & 0 & 7.00 \\
organizations reg & 117 & 2.71 & 2.83 & 0 & 11.00 \\
more than one & 117 & 0.03 & 0.07 & 0 & 0.34 \\
just one & 117 & 0.13 & 0.15 & 0 & 0.53 \\
single-sector & 117 & 0.13 & 0.48 & 0 & 3.00 \\
mutli-sector & 117 & 1.69 & 1.85 & 0 & 7.00 \\
meetings 2002 & 117 & 0.10 & 0.17 & 0 & 0.69 \\
meetings 2003 & 117 & 0.16 & 0.23 & 0 & 0.93 \\
meetings 2004 & 117 & 0.24 & 0.35 & 0 & 1.58 \\
meetings 2005 & 117 & 0.22 & 0.33 & 0 & 1.47 \\
meetings 2006 & 117 & 0.30 & 0.39 & 0 & 1.96 \\
\hline
\end{tabular}


Table 2 - Benchmark

\begin{tabular}{|c|c|c|c|c|c|c|}
\hline & $(1)$ & $(2)$ & $(3)$ & $(4)$ & $(5)$ & $(6)$ \\
\hline & Overall & Non-core & Core & Overall & Non-core & Core \\
\hline \multirow[t]{2}{*}{ break } & $0.1092^{*}$ & $0.2031^{* * *}$ & -0.0703 & $0.2780^{* * *}$ & $0.3479^{* * *}$ & 0.0565 \\
\hline & $(0.0578)$ & $(0.0520)$ & $(0.0678)$ & $(0.0526)$ & $(0.0497)$ & $(0.0675)$ \\
\hline \multirow[t]{2}{*}{ scale } & -0.0022 & -0.0035 & 0.0003 & $-0.0471^{* * *}$ & $-0.0386^{* * *}$ & -0.0105 \\
\hline & $(0.0030)$ & $(0.0026)$ & $(0.0029)$ & $(0.0130)$ & $(0.0121)$ & $(0.0179)$ \\
\hline \multirow[t]{2}{*}{ concentration } & $-0.1541^{* *}$ & $-0.1125^{*}$ & 0.0475 & -0.2588 & -0.1738 & 0.2178 \\
\hline & $(0.0632)$ & $(0.0613)$ & $(0.0575)$ & $(0.2698)$ & $(0.2577)$ & $(0.3304)$ \\
\hline \multirow[t]{2}{*}{ workers } & $0.0001^{* *}$ & $0.0002^{* *}$ & 0.0001 & $0.0008^{* *}$ & $0.0007^{* *}$ & $0.0012^{*}$ \\
\hline & $(0.0001)$ & $(0.0001)$ & $(0.0001)$ & $(0.0004)$ & $(0.0004)$ & $(0.0006)$ \\
\hline \multirow[t]{2}{*}{ earnings } & $-0.0082^{* * *}$ & $-0.0052^{* * *}$ & $-0.0088^{* * *}$ & -0.0010 & 0.0012 & -0.0033 \\
\hline & $(0.0017)$ & $(0.0016)$ & $(0.0019)$ & $(0.0023)$ & (0.0022) & $(0.0030)$ \\
\hline \multirow[t]{2}{*}{ labor share } & -0.0003 & -0.0011 & $0.0066^{* * *}$ & -0.0025 & -0.0035 & 0.0038 \\
\hline & $(0.0016)$ & $(0.0015)$ & $(0.0021)$ & $(0.0043)$ & $(0.0043)$ & $(0.0059)$ \\
\hline \multirow[t]{2}{*}{ unpaid workers } & $-0.0120^{* * *}$ & $-0.0112^{* * *}$ & -0.0051 & $-0.0458^{* *}$ & $-0.0406^{* *}$ & -0.0024 \\
\hline & $(0.0036)$ & $(0.0036)$ & $(0.0031)$ & $(0.0187)$ & $(0.0174)$ & $(0.0205)$ \\
\hline \multirow[t]{2}{*}{ rGd personnel } & -0.0020 & -0.0031 & 0.0012 & -0.0370 & -0.0376 & -0.0053 \\
\hline & $(0.0074)$ & $(0.0072)$ & $(0.0058)$ & $(0.0256)$ & $(0.0243)$ & $(0.0242)$ \\
\hline \multirow[t]{2}{*}{ land } & 0.0070 & 0.0083 & -0.0200 & -0.0071 & -0.0049 & $-0.0486^{* *}$ \\
\hline & (0.0093) & $(0.0084)$ & $(0.0152)$ & $(0.0153)$ & $(0.0136)$ & $(0.0218)$ \\
\hline \multirow[t]{2}{*}{ import penetration } & -0.0049 & -0.0062 & -0.0078 & $0.0898^{* *}$ & $0.1313^{* * *}$ & 0.0452 \\
\hline & $(0.0124)$ & $(0.0122)$ & $(0.0072)$ & $(0.0448)$ & $(0.0399)$ & $(0.0924)$ \\
\hline \multirow[t]{2}{*}{ export/va ratio } & $0.0212^{* *}$ & $0.0301^{* * *}$ & $-0.0178^{*}$ & $-0.1344^{* *}$ & $-0.1365^{* *}$ & $-0.1626^{* *}$ \\
\hline & $(0.0103)$ & $(0.0103)$ & $(0.0104)$ & $(0.0603)$ & $(0.0538)$ & $(0.0748)$ \\
\hline \multirow[t]{2}{*}{ elasticity } & $0.0012^{* *}$ & $0.0015^{* * *}$ & 0.0005 & 0.0011 & 0.0015 & -0.0001 \\
\hline & $(0.0005)$ & $(0.0004)$ & $(0.0004)$ & $(0.0018)$ & $(0.0020)$ & $(0.0018)$ \\
\hline \multirow[t]{2}{*}{ MFN 1999} & $0.0055^{* * *}$ & $0.0063^{* * *}$ & -0.0001 & & & \\
\hline & $(0.0010)$ & $(0.0010)$ & $(0.0006)$ & & & \\
\hline Observations & 8,125 & 8,125 & 8,125 & 8,147 & 8,147 & 8,147 \\
\hline R-squared & 0.301 & 0.334 & 0.158 & 0.377 & 0.443 & 0.275 \\
\hline Product f.e. & No & No & No & Yes & Yes & Yes \\
\hline
\end{tabular}

NOTE: Estimation by least squares; robust standard errors (in parentheses) are clustered at the sector level (4-digit ISIC). Number of clusters $=117$. $* * *$ significant at $1 \% ; *$ significant at $5 \% ;{ }^{*}$ significant at $10 \%$. 
Table 3 - Meetings

\begin{tabular}{|c|c|c|c|c|c|c|c|c|c|}
\hline & (1) & (2) & (3) & (4) & (5) & (6) & (7) & (8) & (9) \\
\hline & Overall & Non-core & Core & Overall & Non-core & Core & Overall & Non-core & Core \\
\hline \multirow[t]{2}{*}{ break } & 0.0943 & $0.1956^{* *}$ & 0.0242 & 0.0799 & $0.1690^{* *}$ & 0.0512 & -0.0132 & 0.0813 & -0.0416 \\
\hline & $(0.0911)$ & $(0.0853)$ & $(0.1074)$ & $(0.0826)$ & $(0.0847)$ & $(0.1024)$ & $(0.0663)$ & $(0.0610)$ & $(0.0867)$ \\
\hline \multirow[t]{2}{*}{ meetings } & $0.4496^{* *}$ & $0.3728^{* *}$ & 0.0790 & $0.4210^{* *}$ & $0.3730^{* *}$ & 0.1682 & $0.5161^{* * *}$ & $0.5131^{* * *}$ & -0.1211 \\
\hline & $(0.1867)$ & $(0.1858)$ & $(0.2030)$ & $(0.1779)$ & $(0.1829)$ & $(0.1877)$ & $(0.1390)$ & $(0.1313)$ & $(0.1787)$ \\
\hline \multirow[t]{2}{*}{ MFN 1999} & & & & & & & $0.0036^{* * *}$ & $0.0044^{* * *}$ & 0.0004 \\
\hline & & & & & & & $(0.0008)$ & $(0.0008)$ & $(0.0006)$ \\
\hline \multirow[t]{2}{*}{ NTM japan } & & & & 0.0319 & $0.0877^{*}$ & 0.0164 & & & \\
\hline & & & & $(0.0343)$ & $(0.0482)$ & $(0.0390)$ & & & \\
\hline \multirow[t]{2}{*}{ NTM india } & & & & $0.0999^{* * *}$ & 0.0384 & $0.1879^{* * *}$ & & & \\
\hline & & & & $(0.0235)$ & $(0.0376)$ & $(0.0252)$ & & & \\
\hline \multirow[t]{2}{*}{ NTM mexico } & & & & -0.0054 & -0.0005 & 0.0215 & & & \\
\hline & & & & $(0.0378)$ & $(0.0415)$ & $(0.0531)$ & & & \\
\hline Obs. & 8,147 & 8,147 & 8,147 & 8,147 & 8,147 & 8,147 & 8,125 & 8,125 & 8,125 \\
\hline R-squared & 0.389 & 0.452 & 0.276 & 0.407 & 0.459 & 0.339 & 0.328 & 0.362 & 0.160 \\
\hline Product f.e. & Yes & Yes & Yes & Yes & Yes & Yes & No & No & No \\
\hline Controls & Yes & Yes & Yes & Yes & Yes & Yes & Yes & Yes & Yes \\
\hline
\end{tabular}

NOTE: Estimation by least squares; robust standard errors (in parentheses) are clustered at the sector level (4-digit ISIC). Number of clusters $=117 .{ }^{* * *}$ significant at $1 \%$; ** significant at $5 \% ;{ }^{*}$ significant at $10 \%$. NTM japan, NTM mexico, and NTM india refer to respectively overall, non-core, and core protection depending on whether the dependent variable of the relevant regression is overall, non-core, and core European protection. Controls include: scale, concentration, workers, earnings, labor share, unpaid workers, r\&̈d personnel, land, import penetration, export/va ratio, and elasticity. 
Table 4 - Registrations and organizations

\begin{tabular}{|c|c|c|c|c|c|c|c|c|c|}
\hline & $\begin{array}{c}(1) \\
\text { Overall }\end{array}$ & $\begin{array}{c}(2) \\
\text { Non-core }\end{array}$ & $\begin{array}{c}(3) \\
\text { Core }\end{array}$ & $\begin{array}{c}(4) \\
\text { Overall }\end{array}$ & $\begin{array}{c}(5) \\
\text { Non-core }\end{array}$ & $\begin{array}{c}(6) \\
\text { Core }\end{array}$ & $\begin{array}{c}(7) \\
\text { Overall }\end{array}$ & $\begin{array}{c}(8) \\
\text { Non-core }\end{array}$ & $\begin{array}{l}(9) \\
\text { Core }\end{array}$ \\
\hline break & $\begin{array}{c}0.0842 \\
(0.0802)\end{array}$ & $\begin{array}{l}0.1726^{* *} \\
(0.0824)\end{array}$ & $\begin{array}{c}0.0963 \\
(0.0991)\end{array}$ & $\begin{array}{c}0.1079 \\
(0.0739)\end{array}$ & $\begin{array}{l}0.1990^{* *} \\
(0.0803)\end{array}$ & $\begin{array}{c}0.1238 \\
(0.0866)\end{array}$ & $\begin{array}{l}0.1474^{* *} \\
(0.0715)\end{array}$ & $\begin{array}{c}0.2119^{* * *} \\
(0.0788)\end{array}$ & $\begin{array}{c}0.1253 \\
(0.0786)\end{array}$ \\
\hline registrations & $\begin{array}{l}0.2610^{* *} \\
(0.1089)\end{array}$ & $\begin{array}{c}0.2296^{* *} \\
(0.1108)\end{array}$ & $\begin{array}{c}0.0357 \\
(0.1189)\end{array}$ & & & & & & \\
\hline organizations & & & & $\begin{array}{c}0.0334^{* *} \\
(0.0138)\end{array}$ & $\begin{array}{c}0.0279^{*} \\
(0.0143)\end{array}$ & $\begin{array}{l}-0.0012 \\
(0.0148)\end{array}$ & & & \\
\hline organization reg. & & & & & & & $\begin{array}{l}0.0180^{*} \\
(0.0094)\end{array}$ & $\begin{array}{c}0.0188^{*} \\
(0.0099)\end{array}$ & $\begin{array}{l}-0.0012 \\
(0.0102)\end{array}$ \\
\hline NTM japan & $\begin{array}{c}0.0296 \\
(0.0347)\end{array}$ & $\begin{array}{c}0.0855^{*} \\
(0.0482)\end{array}$ & $\begin{array}{c}0.0193 \\
(0.0397)\end{array}$ & $\begin{array}{c}0.0294 \\
(0.0350)\end{array}$ & $\begin{array}{l}0.0831^{*} \\
(0.0487)\end{array}$ & $\begin{array}{c}0.0212 \\
(0.0399)\end{array}$ & $\begin{array}{c}0.0311 \\
(0.0363)\end{array}$ & $\begin{array}{c}0.0800 \\
(0.0495)\end{array}$ & $\begin{array}{c}0.0210 \\
(0.0393)\end{array}$ \\
\hline NTM india & $\begin{array}{c}0.1015^{* * *} \\
(0.0235)\end{array}$ & $\begin{array}{c}0.0415 \\
(0.0375)\end{array}$ & $\begin{array}{c}0.1858^{* * *} \\
(0.0255)\end{array}$ & $\begin{array}{c}0.1051^{* * *} \\
(0.0234)\end{array}$ & $\begin{array}{c}0.0448 \\
(0.0363)\end{array}$ & $\begin{array}{c}0.1842^{* * *} \\
(0.0258)\end{array}$ & $\begin{array}{c}0.1005^{* * *} \\
(0.0243)\end{array}$ & $\begin{array}{c}0.0398 \\
(0.0366)\end{array}$ & $\begin{array}{c}0.1841^{* * *} \\
(0.0254)\end{array}$ \\
\hline NTM mexico & $\begin{array}{c}-0.0071 \\
(0.0381)\end{array}$ & $\begin{array}{l}-0.0023 \\
(0.0418)\end{array}$ & $\begin{array}{c}0.0177 \\
(0.0534)\end{array}$ & $\begin{array}{c}-0.0088 \\
(0.0370)\end{array}$ & $\begin{array}{l}-0.0042 \\
(0.0412)\end{array}$ & $\begin{array}{c}0.0148 \\
(0.0535)\end{array}$ & $\begin{array}{l}-0.0046 \\
(0.0356)\end{array}$ & $\begin{array}{l}-0.0006 \\
(0.0399)\end{array}$ & $\begin{array}{c}0.0148 \\
(0.0531)\end{array}$ \\
\hline Observations & 8,147 & 8,147 & 8,147 & 8,147 & 8,147 & 8,147 & 8,147 & 8,147 & 8,147 \\
\hline R-squared & 0.407 & 0.458 & 0.337 & 0.407 & 0.458 & 0.337 & 0.404 & 0.458 & 0.337 \\
\hline Product f.e. & Yes & Yes & Yes & Yes & Yes & Yes & Yes & Yes & Yes \\
\hline Controls & Yes & Yes & Yes & Yes & Yes & Yes & Yes & Yes & Yes \\
\hline
\end{tabular}

NOTE: Estimation by least squares; robust standard errors (in parentheses) are clustered at the sector level (4-digit ISIC). Number of clusters $=117 .{ }^{* * *}$ significant at $1 \% ;{ }^{* *}$ significant at $5 \%{ }^{*}$ significant at $10 \%$. NTM japan, NTM mexico, and NTM india refer to respectively overall, non-core, and core protection depending on whether the dependent variable of the relevant regression is overall, non-core, and core European protection. Controls include: scale, concentration, workers, earnings, labor share, unpaid workers, r\&̈d personnel, land, import penetration, export/va ratio, and elasticity. 
Table 5 - Lobbies' attributes

\begin{tabular}{lcccccc}
\hline & $(1)$ & $(2)$ & $(3)$ & $(4)$ & $(5)$ & $(6)$ \\
& Overall & Non-core & Core & Overall & Non-core & Core \\
\hline break & 0.0707 & $0.1532^{*}$ & 0.0740 & 0.0821 & $0.1708^{* *}$ & 0.1122 \\
& $(0.0826)$ & $(0.0842)$ & $(0.1009)$ & $(0.0764)$ & $(0.0836)$ & $(0.0830)$ \\
more than one & 0.0642 & -0.2400 & $1.0682^{* *}$ & & & \\
& $(0.5148)$ & $(0.4989)$ & $(0.4453)$ & & & \\
just one & $0.5528^{* *}$ & $0.5907^{* *}$ & -0.1619 & & & \\
& $(0.2481)$ & $(0.2498)$ & $(0.2817)$ & & & \\
multi-sector & & & & $0.0449^{* * *}$ & $0.0397^{* *}$ & 0.0041 \\
& & & & $(0.0154)$ & $(0.0164)$ & $(0.0136)$ \\
single-sector & & & & -0.0402 & -0.0503 & -0.0352 \\
& & & & $(0.0364)$ & $(0.0428)$ & $(0.0562)$ \\
NTM japan & 0.0310 & $0.0820^{*}$ & 0.0090 & 0.0269 & $0.0821^{*}$ & 0.0212 \\
& $(0.0345)$ & $(0.0488)$ & $(0.0373)$ & $(0.0351)$ & $(0.0481)$ & $(0.0400)$ \\
NTM india & $0.1005^{* * *}$ & 0.0438 & $0.1883^{* * *}$ & $0.1085^{* * *}$ & 0.0504 & $0.1850^{* * *}$ \\
& $(0.0235)$ & $(0.0365)$ & $(0.0252)$ & $(0.0231)$ & $(0.0366)$ & $(0.0253)$ \\
NTM mexico & -0.0003 & 0.0064 & 0.0238 & -0.0126 & -0.0095 & 0.0171 \\
& $(0.0390)$ & $(0.0429)$ & $(0.0531)$ & $(0.0367)$ & $(0.0411)$ & $(0.0530)$ \\
& & & & & & \\
Observations & 8,147 & 8,147 & 8,147 & 8,147 & 8,147 & 8,147 \\
R-squared & 0.408 & 0.462 & 0.347 & 0.412 & 0.464 & 0.338 \\
Product f.e. & Yes & Yes & Yes & Yes & Yes & Yes \\
Controls & Yes & Yes & Yes & Yes & Yes & Yes \\
\hline
\end{tabular}

NOTE: Estimation by least squares; robust standard errors (in parentheses) are clustered at the sector level (4-digit ISIC). Number of clusters $=117$. *** significant at $1 \%$; ** significant at $5 \%$; ${ }^{*}$ significant at $10 \%$. NTM japan, NTM mexico, and NTM india refer to respectively overall, non-core, and core protection depending on whether the dependent variable of the relevant regression is overall, non-core, and core European protection. Controls include: scale, concentration, workers, earnings, labor share, unpaid workers, rध̈d personnel, land, import penetration, export/va ratio, and elasticity. 
Table 6 - Protection for sale

\begin{tabular}{lcccccc}
\hline & $(1)$ & $(2)$ & $(3)$ & $(4)$ & $(5)$ & $(6)$ \\
& Overall & Non-core & Core & Overall & Non-core & Core \\
\hline break & $0.2743^{* * *}$ & $0.3450^{* * *}$ & 0.0508 & 0.1037 & $0.2097^{* *}$ & 0.0307 \\
& $(0.0538)$ & $(0.0549)$ & $(0.0659)$ & $(0.0927)$ & $(0.0924)$ & $(0.1077)$ \\
meetings & & & & $0.4195^{* *}$ & $0.3329^{*}$ & 0.0496 \\
& & & & $(0.1966)$ & $(0.1982)$ & $(0.2100)$ \\
$g h$ & $0.0014^{*}$ & 0.0012 & 0.0001 & 0.0010 & 0.0009 & 0.0000 \\
& $(0.0008)$ & $(0.0008)$ & $(0.0011)$ & $(0.0008)$ & $(0.0008)$ & $(0.0011)$ \\
& & & & & & \\
Observations & 7,834 & 7,834 & 7,834 & 7,834 & 7,834 & 7,834 \\
R-squared & 0.374 & 0.443 & 0.274 & 0.385 & 0.439 & 0.275 \\
Product f.e. & Yes & Yes & Yes & Yes & Yes & Yes \\
Controls & Yes & Yes & Yes & Yes & Yes & Yes \\
\hline
\end{tabular}

NOTE: Estimation by least squares; robust standard errors (in parentheses) are clustered at the sector level (4digit ISIC). Number of clusters $=117 . * * *$ significant at $1 \% ; * *$ significant at $5 \% ; *$ significant at $10 \%$. Controls include: scale, concentration, workers, earnings, labor share, unpaid workers, r\&d personnel, land, import penetration, export/va ratio, and elasticity. 
Figure 1A - Average frequency ratios across countries

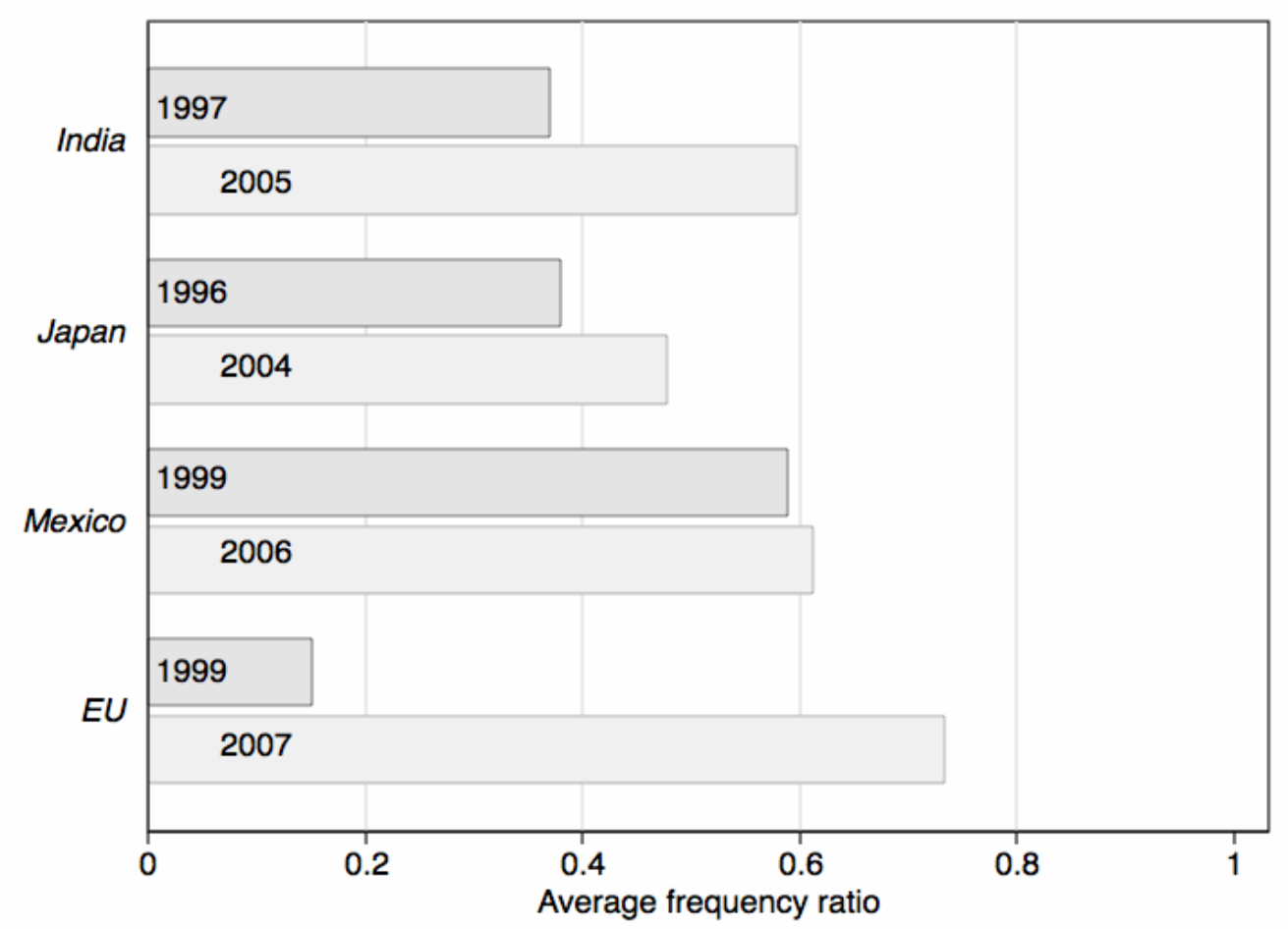

NOTE: The average frequency ratio is a synthetic measure computed as the average number of 6-digit HS imported products subject to at least one non-tariff barrier as a percentage of the total number of products. Source: TRAINSUNCTAD (2013)

Figure 1B - Frequency ratios and attended meetings in EU

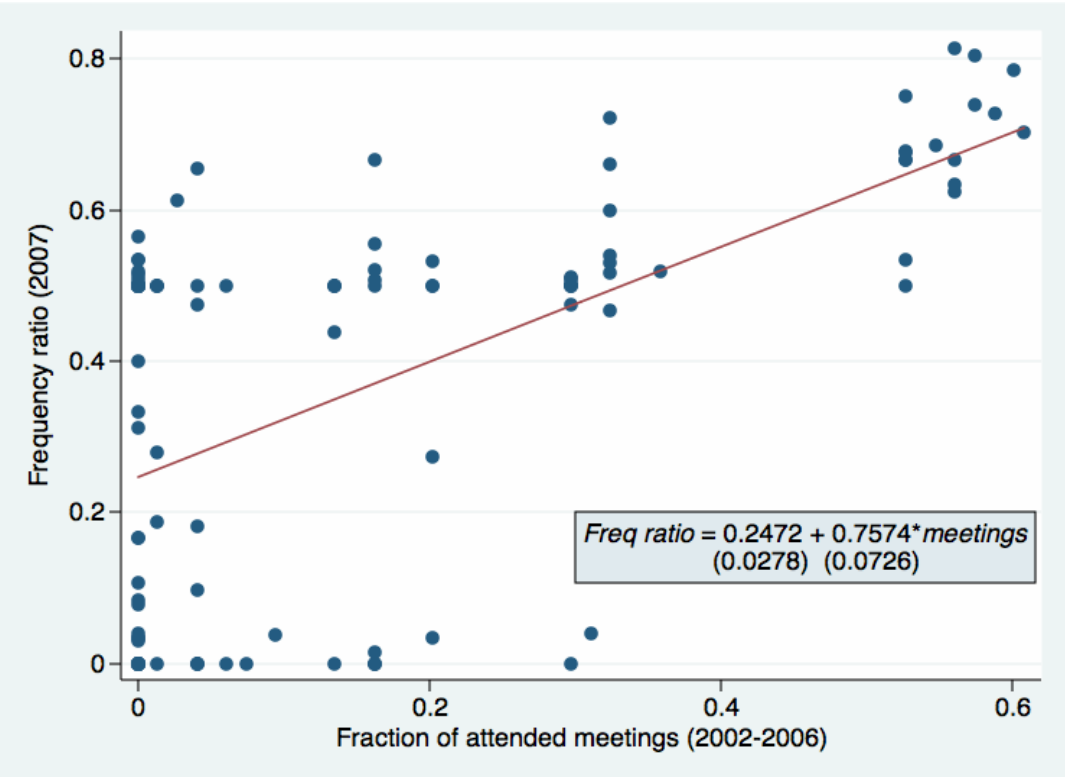

NOTE: Frequency ratio is the average frequency ratio across industries (4-digit ISIC) obtained as the percentage of imported product categories subject to NTMs in each 6-digit HS product group (as defined in subsection 4.1). Source: TRAINS-UNCTAD (2013). Fraction of attended meetings is the fraction of meetings organized by the DG Trade Civic Society Dialogue attended by at least one organization in each industry (4-digit ISIC) group between 2002 and 2006. Source: European Commission (2012). 
Figure 2 - Coverage ratios

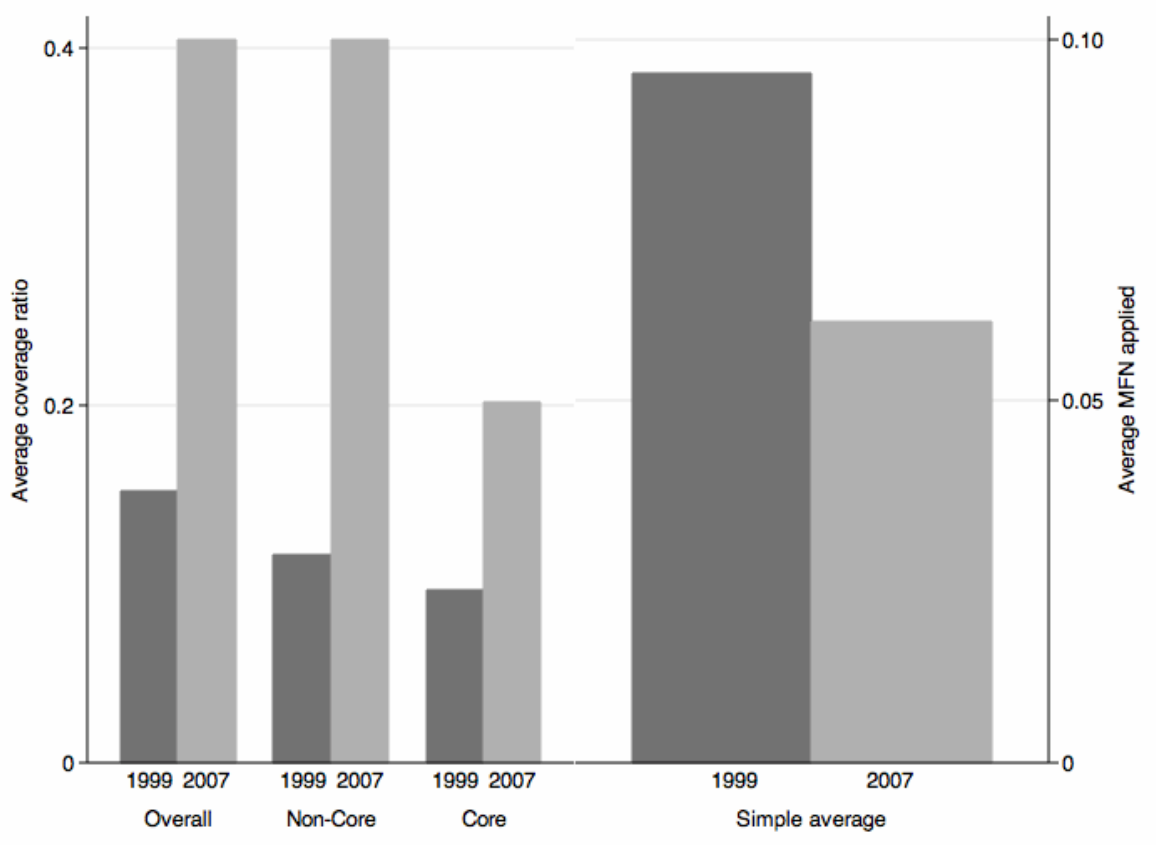

NOTE: Coverage ratio is the industry (4-digit ISIC) average coverage ratio for overall NTMs - Source: TRAINSUNCTAD (2013). Fraction of attended meetings is the fraction of meetings in the 2002-2006 period attended by at least one organization in each industrial sector (4-digit ISIC) - Source: European Commission (2012). 
Figure 3 - Registrations with and without attendance

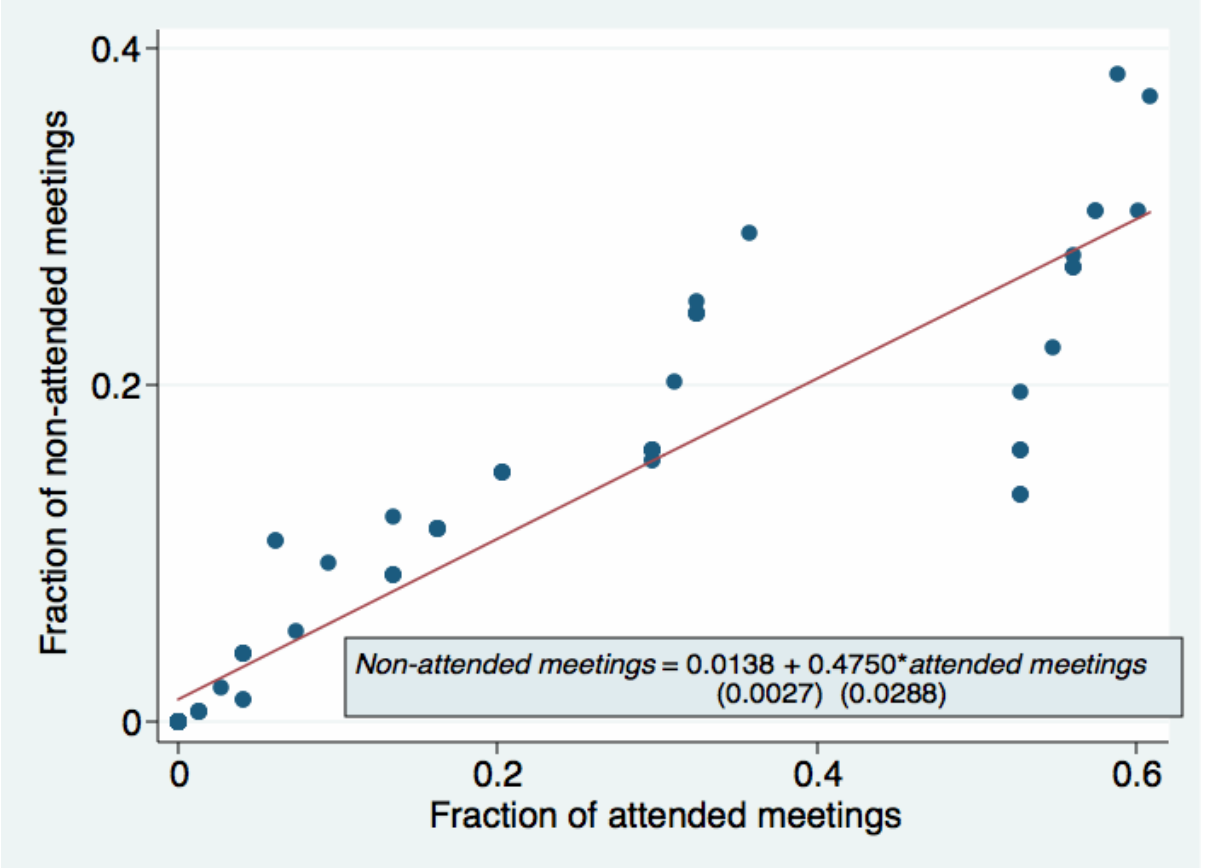

NOTE: Fraction of non-attended meetings registration is the fraction of meetings in the 2002-2006 period in which at least one organization in each industrial sector (4-digit ISIC) registered and then did not show up. Fraction of attended meetings is the fraction of meetings in the 2002-2006 period attended by at least one organization in each industrial sector (4-digit ISIC) - Source: European Commission (2012). 